Jurnal Gizi dan Dietetik Indonesia (Indonesian Journal of Nutrition and Dietetics) Vol. 8, No. 2, 2020: 68-79
Available online at: http://ejournal.almaata.ac.id/index.php/IJND DOI : http://dx.doi.org/10.21927/ijnd.2020.8(2).68-79

\title{
Assessing preconception nutrition readiness among women of reproductive age in Bantul, Indonesia: findings from baseline data analysis of a cluster randomized trial
}

\author{
Yhona Paratmanitya ${ }^{1,2}$, Siti Helmyati ${ }^{3}$, Detty S. Nurdiati ${ }^{4}$, Emma C. Lewis ${ }^{5}$, Hamam Hadi $6,7^{\star}$
}

${ }^{1}$ Department of Nutrition, Faculty of Health Sciences, Universitas Alma Ata, Jalan Brawijaya No. 99, Yogyakarta 55183, Indonesia

${ }^{2}$ Postgraduate Student, Faculty of Medicine, Public Health, and Nursing, Universitas Gadjah Mada, Jalan Farmako, Sekip Utara, Yogyakarta 55281, Indonesia

${ }^{3}$ Department of Nutrition and Health, Faculty of Medicine, Public Health, and Nursing, Universitas Gadjah Mada, Jalan Farmako, Sekip Utara, Yogyakarta 55281, Indonesia

${ }^{4}$ Department of Obstetric \& Gynecology, Faculty of Medicine, Public Health, and Nursing,

Universitas Gadjah Mada, Jalan Farmako, Sekip Utara, Yogyakarta 55281, Indonesia

${ }^{5}$ Human Nutrition, International Health, Johns Hopkins Bloomberg School of Public Health, Baltimore, MD, USA ${ }^{6}$ Graduate School of Public Health, Universitas Alma Ata, Jalan Brawijaya 99, Tamantirto Yogyakarta 55183, Indonesia.

${ }^{7}$ Director of Community-Alma Ata Partnership Through Updated Research and Education (CAPTURE), Universitas Alma Ata, Yogyakarta, Indonesia. Tel.: +62-274-4342288

*Corresponding author: hhadi@almaata.ac.id

\begin{abstract}
ABSTRAK
Latar Belakang: Pemenuhan gizi pada masa prakonsepsi merupakan hal yang penting untuk memastikan kehamilan yang sehat, namun banyak wanita di negara-negara berkembang yang belum menyadari pentingnya hal tersebut. Informasi tentang kesiapan gizi prakonsepsi pada wanita usia subur, khususnya di negara berkembang, masih terbatas.

Tujuan: Untuk mengetahui kesiapan gizi prakonsepsi pada calon pengantin wanita di Indonesia Metode: Penelitian ini merupakan bagian dari studi cluster randomized trial untuk meningkatkan status besi ibu hamil di Kabupaten Bantul, Yogyakarta, yang melibatkan 173 calon pengantin wanita. Data antropometri, asupan makan, dan pengetahuan tentang gizi prakonsepsi dikumpulkan oleh enumerator yang terlatih, yaitu mahasiswa di Fakultas Kesehatan, Universitas Alma Ata, dengan melakukan kunjungan ke rumah responden. Data kadar Hemoglobin $(\mathrm{Hb})$ diperoleh melalui kuesioner. Kesiapan gizi prakonsepsi diukur menggunakan 10 indikator, yang meliput: (1) Indeks Massa Tubuh (IMT); (2) Lingkar Lengan Atas (LILA); (3) kadar Hb; (4) asupan energi; (5) asupan protein; (6) asupan kalsium; (7) asupan zat besi; (8) asupan folat; (9) pengetahuan tentang gizi prakonsepsi; dan (10) konsumsi suplemen zat besi dan/atau asam folat. Skor kesiapan akan berkisar antara 0-10.

Hasil: Tidak ada satupun responden yang dapat memenuhi seluruh indikator kesiapan gizi prakonsepsi. Sebanyak 26\% responden dapat memenuhi 2 indikator, dan median skor-nya adalah 3 (2.0-4.0). Kadar Hb, IMT, dan LILA merupakan 3 indikator terbanyak yang dapat dipenuhi, sementara asupan kalsium, zat besi, dan folat merupakan 3 indikator yang paling sedikit dapat dipenuhi oleh responden.

Kesimpulan: Peningkatan kesadaran akan pentingnya mempersiapkan gizi prakonsepsi pada calon ibu merupakan hal yang sangat diperlukan. Program intervensi gizi kedepannya sebaiknya sudah dimulai sejak masa prakonsepsi, bukan hanya fokus pada kehamilan.
\end{abstract}

KATA KUNCI: indeks massa tubuh; asupan makan; prakonsepsi; wanita usia subur

\section{ABSTRACT}

Background: Proper nutrition during preconception is essential to ensuring a healthy pregnancy, however, women in developing countries may not be aware of its importance. Information is limited regarding nutrition readiness prior to conception among women of reproductive age in these settings. 
Objective: To examine nutrition readiness prior to conception among premarital women living in Indonesia. Methods: This study was part of a cluster randomized trial which aimed to improve the iron status of pregnant women in Bantul District, Yogyakarta, Indonesia. A total of 173 premarital women were included in the study. Data were collected on anthropometry, dietary intake, and knowledge about preconception nutrition by trained nutrition students of the University of Alma Ata, and taking place in the participant's home. Hemoglobin level data were obtained based on answers to a questionnaire. Preconception nutrition readiness for pregnancy was determined based on 10 indicators, including: (1) body mass index (BMI); (2) mid-upper arm circumference (MUAC); (3) hemoglobin ( $\mathrm{Hb}$ ) level; average daily intakes for (4) energy, (5) protein, (6) calcium, (7) iron, and (8) folic acid; (9) level of knowledge about preconception nutrition; and (10) folic acid and/or iron supplement consumption. Preconception nutrition readiness scores ranged from 0-10.

Results: No study participants met all 10 indicators for preconception nutrition readiness. One-quarter (26.0\%) of participants could only meet 2 indicators, and the median score was 3.0 (2.0-4.0). Hb level, $B M I$, and MUAC were the 3 indicators met most by participants, while iron, folic acid, and calcium intake were the least met indicators.

Conclusion: Raising awareness about preconception nutritional preparation among women of reproductive age is urgent. Future nutrition intervention programs should target the preconception period.

KEYWORDS: body mass index, dietary intake, preconception, women of reproductive age.

\section{INTRODUCTION}

Maternal health, and particularly nutrition, during preconception and pregnancy greatly impact the health and nutritional status of the newborn child over the short- and long-term(1-3). Recent reviews have found that interventions during the preconception stage have the potential to result in improved pregnancy outcomes(4-7). The process of fetal development begins before a woman realizes that she is pregnant, so it is important to ensure that women are adequately knowledgeable and prepared for pregnancy before conception occurs. The World Health Organization (WHO) recommends that preconception health services be incorporated into maternal and child health services in all countries because of the potential benefits to both maternal and child health(8).

Awareness of the importance of preparing for a healthy pregnancy is not widely shared among women of reproductive age. One particular study that took place in Southampton, UK found that women were motivated to change their health behaviors for the better when they were pregnant(9). Unfortunately, there is a high prevalence of health problems among mothers and children because many women enter pregnancy with pre-existing conditions that are not addressed prior to conception. The Indonesian Basic
Health Survey (2018) found that there is a high prevalence of anemia in pregnant women (48.9\%) and in all women (27.2\%). The survey also found that around 17 percent (17.3\%) of pregnant women were at risk of chronic energy deficiency, whereas the prevalence among non-pregnant women was $14.5 \%(10)$. The average iron, folic acid, and calcium intakes among non-pregnant Indonesian women of reproductive age were only $14.39( \pm 4.68) \mathrm{mg}$, $259.81( \pm 83.53) \mathrm{mcg}$, and $389.37( \pm 159.14) \mathrm{mg}$, respectively(11). Compared to Recommended Daily Allowance (RDA) for the Indonesian population, those intakes only fulfilled $79,9 \%$ of RDA for iron, $64,9 \%$ of RDA for folic acid, and $38,9 \%$ of RDA for calcium. The average of energy, protein, and iron intakes in Indonesian pregnant women were $1178.4( \pm 449.6) \mathrm{kcal} /$ day, $38.4( \pm 18.7) \mathrm{g} /$ day, and 7.7 ( $\pm 6.2 \mathrm{mg} /$ day) respectively, representing to only $54.7 \%, 57.4 \%$, and $29.5 \%$ of the Indonesian nutrient requirement of energy, protein, and iron intakes for pregnant women(12).

Nutrition is one of the most important factors to be considered when a woman begins planning a pregnancy. Previous studies have confirmed that poor nutritional conditions during the preconception stage can affect pregnancy outcomes, both mother and baby(2,5,13-16). Despite this knowledge, it is rare for a woman to be assessed on her 
nutrition readiness prior to pregnancy, especially in Indonesia. Furthermore, previous studies in this area have only measured the adequacy of food intake, nutritional status, knowledge about preconception nutrition, or consumption of folic acid supplements as separate measures but not taken together(17-19). The current study aims to close this gap in the literature by measuring nutrition readiness for pregnancy across ten nutrition-related indicators. These indicators were chosen based on risk factors associated with maternal and childhood mortality and morbidity as identified by the WHO. Some nutrition-related health problems of particular concern include maternal underweight, maternal overweight/obesity, folic acid insufficiency, irondeficiency anemia, untreated diabetes mellitus, calcium deficiency, and iodine deficiency(20).

Indonesia is a developing country, and as such, does not yet have a national-level intervention program aimed at optimizing women's health during the preconception period. Presently, no data exist relating to preconception nutrition readiness among women of reproductive age. Therefore, the current study aims to provide an overview of preconception nutrition readiness among women of reproductive age based on indicators representing pressing health conditions such that a comprehensive program can be developed to improve the preparedness of all women prior to pregnancy.

\section{MATERIALS AND METHODS}

The current study analyzed the baseline data of a cluster randomized trial conducted among women of reproductive age planning pregnancy. The trial was conducted in three sub-districts of Bantul District, Yogyakarta, Indonesia, starting in January 2019 and ending in February 2020. Sedayu, Pajangan, and Pleret Sub-Districts were chosen based on their high prevalence of anemia during pregnancy. The 122 clusters divided randomly into intervention groups and control groups. The intervention groups received a mentoring program from preconception until pregnancy, whereas the control groups received usual routine health services. This study was done as a part of the Public
Health Surveillance (PHS) activity carried out by CAPTURE (Community - Alma Ata Partnership Through Updated Research and Education) within the University of Alma Ata, Yogyakarta, Indonesia.

One hundred and seventy three women met the inclusion criteria and were included in the present analysis. Women who (1) were already pregnant at the time of data collection; (2) did not have $\mathrm{Hb}$ level data; (3) did not complete the dietary intake data; or (4) did not fill out the preconception nutrition knowledge questionnaire, were excluded from analyses. The ethical clearance of the study was approved by the Medical and Health Research Ethics Committee (MHREC), Faculty of Medicine, Public Health, and Nursing, Universitas Gadjah Mada, Yogyakarta, Indonesia.

In the context of this paper, preconception nutrition readiness for a healthy pregnancy was measured using ten indicators (Table 1) including: (1) body mass index (BMI); (2) mid-upper arm circumference (MUAC); (3) hemoglobin ( $\mathrm{Hb}$ ) level; average daily intakes for (4) energy, (5) protein, (6) calcium, (7) iron, and (8) folic acid; (9) level of knowledge about preconception nutrition; and (10) folic acid and/or iron supplement consumption. The total score ranged between $0-10$, with a higher score meaning that more indicators were adequately met, and thus indicating greater readiness for a healthy pregnancy. These indicators were chosen based on pressing nutrition-related health problems that have been identified as contributing to maternal and childhood mortality and morbidity by the $\mathrm{WHO}(20)$.

$\mathrm{BMI}$ was used to determine current nutritional status, which was computed as weight $(\mathrm{kg}) /$ height $^{2}$ $\left(\mathrm{m}^{2}\right)$. The classification of BMI followed guidelines from the Indonesian Ministry of Health(21). Women with a BMI lower than $18.5 \mathrm{~kg} / \mathrm{m} 2$ were categorized as underweight, women with a BMI $18.5-25.0 \mathrm{~kg} /$ $\mathrm{m} 2$ were categorized as normal weight, women with a BMI between $25.1-27.0 \mathrm{~kg} / \mathrm{m} 2$ were categorized as overweight, and women with a BMI $>27.0 \mathrm{~kg} /$ $\mathrm{m} 2$ were categorized as obese. Body weight was measured using electronic body scale with an accuracy of $0.1 \mathrm{~kg}$, and body height was measured by GEA Stature Meter with an accuracy of $0.1 \mathrm{~cm}$. MUAC was measured using plastic measuring tape 
by looping the tape at the mid-point between the tip of the shoulder and the tip of the elbow of the left upper arm. A MUAC lower than $23.5 \mathrm{~cm}$ was categorized as at risk of chronic energy deficiency. $\mathrm{Hb}$ level data were obtained from participants, who were asked in a questionnaire, "have you checked your $\mathrm{Hb}$ level in the last 3 months?". If the participant answered "yes", then she was asked to write down her $\mathrm{Hb}$ measurement results. Respondents will be categorized as anemia if their $\mathrm{Hb}$ level were less than $12 \mathrm{~g} / \mathrm{dl}$. Similarly, data for consumption of folic acid supplements and iron were obtained based on participant answers to questions regarding whether or not certain supplements have been taking the supplements in the last 3 months. Women were considered nutritionally ready if they had (1) a normal BMI (18.5-25.0 kg/m²); (2) MUAC $\geq 23.5 \mathrm{~cm}$; (3) hemoglobin $(\mathrm{Hb})$ level $\geq 12 \mathrm{~g} / \mathrm{dl}$; (4-8) average daily intakes for energy, protein, calcium, iron and folic acid $\geq 80 \%$ of the RDA; (9) a good level of knowledge about preconception nutrition $(\geq 75 \%$ of the questions answered correctly), and (10) already consumed folic acid and/or iron supplements.

Data on dietary intake in the last 3 months was collected through interviews using the Semi Quantitative - Food Frequency Questionnaire (SQ-FFQ) which contained 148 types of food that are commonly consumed in the study area. The dietary data were then analyzed using NutriSurvey ${ }^{\circledR}$ in order to calculate the mean daily intakes of energy, protein, calcium, iron, and folic acid of each participant. To measure nutrient adequacy, the mean daily dietary intake was divided by the reference intake (Recommended Dietary Allowance/RDA) and then categorized into either $<80 \%$ of the RDA or $\geq 80 \%$ of RDA. The Indonesian RDA was based on Regulation of Minister of Health, Republic of Indonesia Number 28/2019. Data on knowledge were obtained from a validated questionnaire containing 25 questions related to preconception nutrition (internal consistency Cronbach's alpha= $0.7)$.

Data were analyzed with statistical significance accepted at $\mathrm{P}<0.05$ for all tests. Frequency distributions were employed for categorical data, mean and standard deviation (SD) for normally distributed continuous data, and median and interquartile range (IQR) for non-normal data.

Table 1: Preconception nutrition readiness score

\begin{tabular}{|c|c|c|}
\hline Indicators & $\begin{array}{l}\text { Measurement } \\
\text { category }\end{array}$ & Score \\
\hline $1^{\text {st }}$ indicator: & $\mathrm{BMI}<18.5 \mathrm{~kg} / \mathrm{m}^{2}$ & 0 \\
\hline Nutritional status & $\begin{array}{l}\text { BMI } 18.5-25.0 \mathrm{~kg} / \mathrm{m}^{2} \\
\mathrm{BMI}>25.0 \mathrm{~kg} / \mathrm{m}^{2}\end{array}$ & $\begin{array}{l}1 \\
0\end{array}$ \\
\hline $2^{\text {nd }}$ indicator: Risk & MUAC $<23.5 \mathrm{~cm}$ & 0 \\
\hline $\begin{array}{l}\text { of chronic energy } \\
\text { deficiency }\end{array}$ & $M U A C \geq 23.5 \mathrm{~cm}$ & 1 \\
\hline $\begin{array}{l}3^{\text {rd }} \text { indicator: } \mathrm{Hb} \\
\text { level }\end{array}$ & $\begin{array}{l}\mathrm{Hb} \text { level }<12.0 \mathrm{~g} / \mathrm{dl} \\
\mathrm{Hb} \text { level } \geq 12.0 \mathrm{~g} / \mathrm{dl}\end{array}$ & $\begin{array}{l}0 \\
1\end{array}$ \\
\hline $4^{\text {th }}$ indicator: & $<80 \%$ of the RDA & 0 \\
\hline Energy intake & $\geq 80 \%$ of the RDA & 1 \\
\hline $5^{\text {th }}$ indicator: & $<80 \%$ of the RDA & 0 \\
\hline Protein intake & $\geq 80 \%$ of the RDA & 1 \\
\hline $\begin{array}{l}6^{\text {th }} \text { indicator: Iron } \\
\text { intake }\end{array}$ & $\begin{array}{l}<80 \% \text { of the RDA } \\
\geq 80 \% \text { of the RDA }\end{array}$ & $\begin{array}{l}0 \\
1\end{array}$ \\
\hline $\begin{array}{l}7^{\text {th }} \text { indicator: Folic } \\
\text { acid intake }\end{array}$ & $\begin{array}{l}<80 \% \text { of the RDA } \\
\geq 80 \% \text { of the RDA }\end{array}$ & $\begin{array}{l}0 \\
1\end{array}$ \\
\hline $\begin{array}{l}8^{\text {th }} \text { indicator: } \\
\text { Calcium intake }\end{array}$ & $\begin{array}{l}<80 \% \text { of the RDA } \\
\geq 80 \% \text { of the RDA }\end{array}$ & $\begin{array}{l}0 \\
1\end{array}$ \\
\hline $\begin{array}{l}9^{\text {th }} \text { indicator: } \\
\text { Level of } \\
\text { knowledge about } \\
\text { preconception } \\
\text { nutrition }\end{array}$ & $\begin{array}{l}\text { Poor ( }<75 \% \text { of the } \\
\text { questions answered } \\
\text { correctly) } \\
\text { Good ( } \geq 75 \% \text { of the } \\
\text { questions answered } \\
\text { correctly) }\end{array}$ & $\begin{array}{l}0 \\
1\end{array}$ \\
\hline $\begin{array}{l}10^{\text {th }} \text { indicator: Folic } \\
\text { acid and/or Iron } \\
\text { supplement use }\end{array}$ & $\begin{array}{l}\text { Have not consumed } \\
\text { Already consuming }\end{array}$ & $\begin{array}{l}0 \\
1\end{array}$ \\
\hline
\end{tabular}

\section{RESULTS}

The socio-demographic characteristics of the sample are shown in Table 2 . The majority $(89.6 \%)$ of the participants were between $20-35$ years of age. Most $(64.7 \%)$ of the respondents had middle-school education, and $72.8 \%$ were currently working. Among working women, $60.3 \%$ earned less than the district minimum monthly wage. There was no significant difference between intervention and control groups in all socio-demographic characteristics.

Related to preconception nutrition readiness indicators, as displayed in Figure 1, the indicator that was met by the most participants was the $3^{\text {rd }}$ indicator (anemia status), wherein $76.9 \%$ of participants were found to not be anemic. Meanwhile, the indicator with the lowest percentage of participants meeting it 
Table 2: Socio-demographic characteristics of the subjects $(n=173)$

\begin{tabular}{|c|c|c|c|c|}
\hline \multirow[b]{2}{*}{ Characteristics } & \multirow[b]{2}{*}{ Median (IQR) } & \multicolumn{2}{|c|}{$\mathrm{n}(\%)$} & \multirow[b]{2}{*}{ P-value } \\
\hline & & $\begin{array}{l}\text { Intervention } \\
\text { group }(n=96)\end{array}$ & $\begin{array}{c}\text { Control group } \\
(n=77)\end{array}$ & \\
\hline \multicolumn{5}{|l|}{ Age, years } \\
\hline$<20$ and $>35$ & $24.00(22.00-27.00)$ & $7(7.3)$ & $10(13.0)$ & 0.211 \\
\hline $20-35$ & & $89(92.7)$ & $67(87.0)$ & \\
\hline \multicolumn{5}{|l|}{ Educational background, years } \\
\hline $0-9$ & & $8(8.3)$ & $12(15.6)$ & \\
\hline $10-12$ & & $64(66.7)$ & $48(62.3)$ & 0.329 \\
\hline$>12$ & & $24(25.0)$ & $17(22.1)$ & \\
\hline \multicolumn{5}{|l|}{ Working status } \\
\hline Not working & & $25(26.0)$ & $22(28.6)$ & 0.710 \\
\hline Working & & $71(74.0)$ & $55(71.4)$ & \\
\hline \multicolumn{5}{|l|}{ Monthly income, rupiahs ${ }^{a}$} \\
\hline$<$ district minimum monthly wage & $1.600 .000(1.300 .000-$ & $44(62.0)$ & $32(58.2)$ & 0.666 \\
\hline$\geq$ district minimum monthly wage & $2.000 .000)$ & $27(38.0)$ & $23(41.8)$ & \\
\hline
\end{tabular}

a Of 126 working women. Minimum monthly wage of Bantul District in 2019 was Rp. 1.649 .800 ( \pm 115 USD), based on the governor's decree.

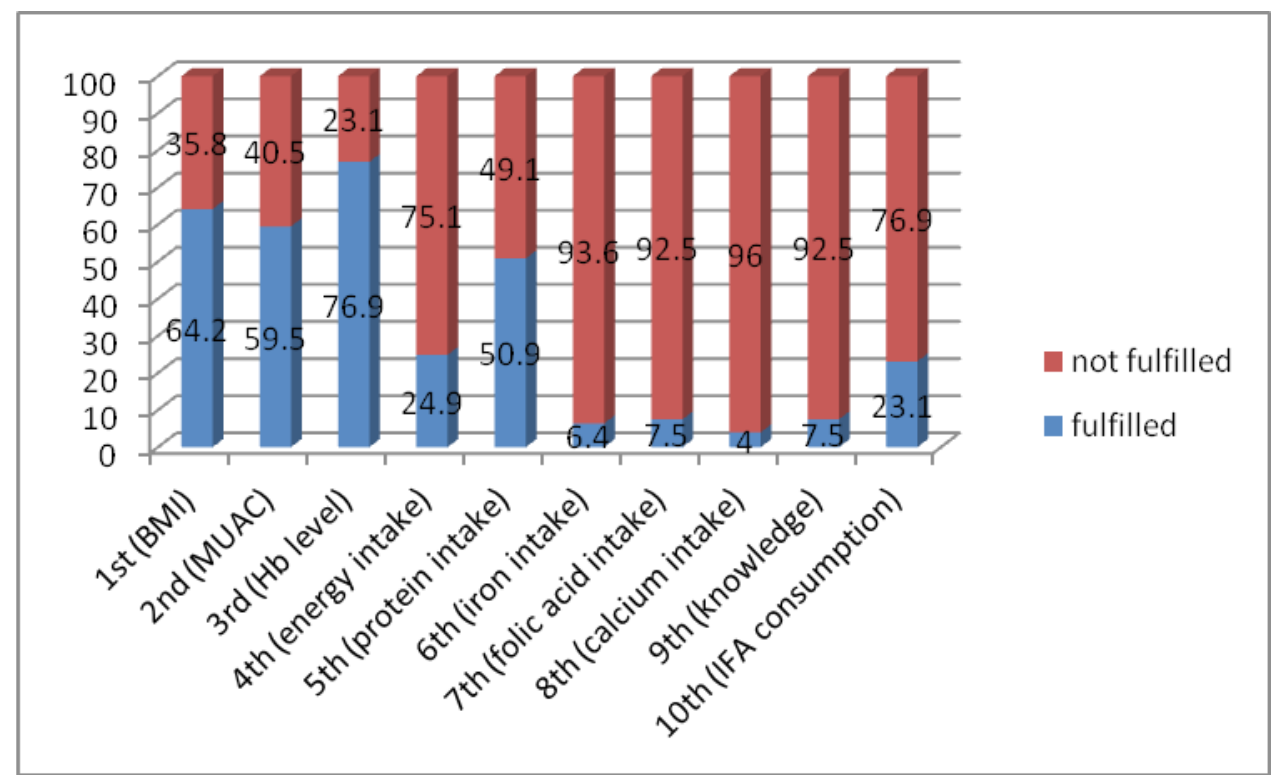

Fig. 1: Percentage of each indicators fulfillment

was calcium intake ( $7^{\text {th }}$ indicator), wherein only $4.0 \%$ of participants met the cut-point of $\geq 80 \%$ of the RDA.

Most $(64.2 \%)$ of the participants had a normal BMI and the majority $(59.5 \%)$ were not at risk of chronic energy deficiency. In regards to the other four indicators related to dietary intake, the majority of participants did not meet the $\geq 80 \%$ of the RDA cut-point. Only $24.9 \%$ of the participants achieved $\geq 80 \%$ of the RDA for energy intake, and for micronutrient intake (calcium, iron, and folic acid), the percentage of participants who met the $\geq 80 \%$ of the RDA cut-point was still less than $8 \%$. For protein intake, about half (50.9\%) of participants met a minimum of $80 \%$ of the RDA. Only $7.5 \%$ of participants had an adequate level of knowledge about preconception nutrition, and only $23.1 \%$ of participants were already consuming iron and/or folic acid in their preconception period.

Based on Figure 2, it is apparent that the majority of participants received a preconception nutrition readiness score of between 2.0 to 4.0 (median $=3.0)$. Only $8.7 \%$ of the participants 


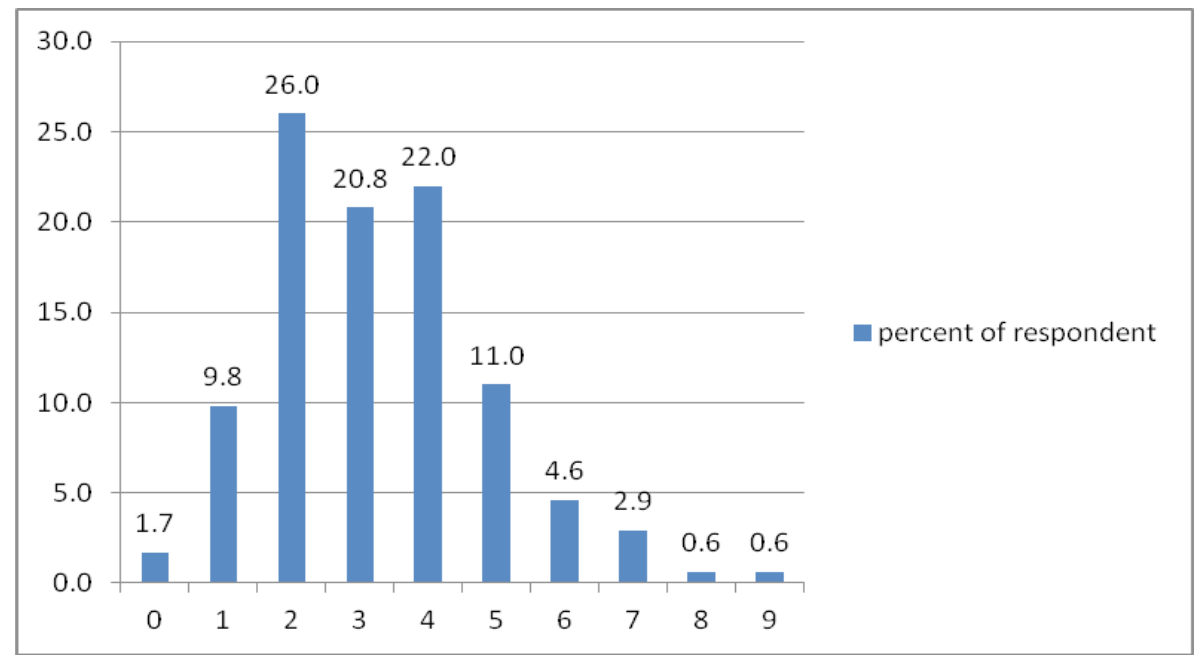

Fig. 2: Percentage of the respondent based on the obtaining score of preconception nutritional readiness

received a score higher than 5.0. The mean score was not statistically different by age, educational background, working status and income level (Table 3).

Figures 3-A and 3-B show that the average intake of energy, protein, iron, folic acid and calcium tended to increase with increasing readiness score obtained. Participants who only met one indicator had a lower average of adequate food intake than those who met more than one indicator. The more scores obtained, the higher the average food intake. The levels of $\mathrm{Hb}, \mathrm{BMI}$, and MUAC also tended to increase with increasing readiness scores (Fig. 3-C). Participants who met more indicators tended to have a higher average of $\mathrm{Hb}, \mathrm{MUAC}$ and $\mathrm{BMI}$.

\section{DISCUSSION}

In the current study, none of the participants $(n=173)$ met all ten indicators of preconception nutrition readiness. In fact, only $8.7 \%$ of the participants fulfilled 5-9 indicators. Indicators with the lowest level of fulfillment were those related to micronutrient intake (iron, folic acid, and calcium). More than $90 \%$ of participants reported iron, folic acid, and calcium intakes below the recommendation ( $<80 \%$ of the RDA). In line with our findings, the UK National Diet and Nutrition Survey found that $96 \%$ of non-pregnant women of reproductive age were unable to meet the RDA for folic acid intake, $91 \%$
Table 3: The mean difference of preconception nutrition readiness score based on characteristics of the subjects

\begin{tabular}{|c|c|c|c|}
\hline Characteristics & $\mathbf{n}$ & $\begin{array}{l}\text { Mean of the } \\
\text { readiness } \\
\text { score }\end{array}$ & P-value \\
\hline \multicolumn{4}{|l|}{ Age, years } \\
\hline$<20$ & 9 & $2.67( \pm 1.58)$ & $0.409^{b}$ \\
\hline $20-35$ & 155 & $3.26( \pm 1.61)$ & \\
\hline$>35$ & 9 & $3.56( \pm 2.01)$ & \\
\hline \multicolumn{4}{|l|}{$\begin{array}{l}\text { Educational } \\
\text { background, years }\end{array}$} \\
\hline $0-9$ & 20 & $3.25( \pm 1.52)$ & $0.942^{\mathrm{b}}$ \\
\hline $10-12$ & 112 & $3.28( \pm 1.71)$ & \\
\hline$>12$ & 41 & $3.17( \pm 1.48)$ & \\
\hline \multicolumn{4}{|l|}{ Working status } \\
\hline Not working & 47 & $3.11( \pm 1.59)$ & $0.617^{c}$ \\
\hline Working & 126 & $3.30( \pm 1.65)$ & \\
\hline \multicolumn{4}{|l|}{ Income level ${ }^{a}$} \\
\hline $\begin{array}{l}\text { <district minimum } \\
\text { monthly wage }\end{array}$ & 76 & $3.29( \pm 1.76)$ & $0.714^{\mathrm{c}}$ \\
\hline $\begin{array}{l}\geq \text { district minimum } \\
\text { monthly wage }\end{array}$ & 49 & $3.32( \pm 1.48)$ & \\
\hline
\end{tabular}

a Of 126 working women, ${ }^{b}$ analyzed with Kruskal-Wallis test, ${ }^{\mathrm{c}}$ analyzed with Mann-Whitney test

were unable to meet the RDA for calcium intake, and $70 \%$ for unable to meet the RDA for iron intake.(13)

Adequate intake for these micronutrients is particularly important during the preconception period because of the potential to improve women's health and prevent adverse outcomes of pregnancy. $(20,22)$ However, it is hard to meet the RDA for these micronutrient through diet alone, and thus 

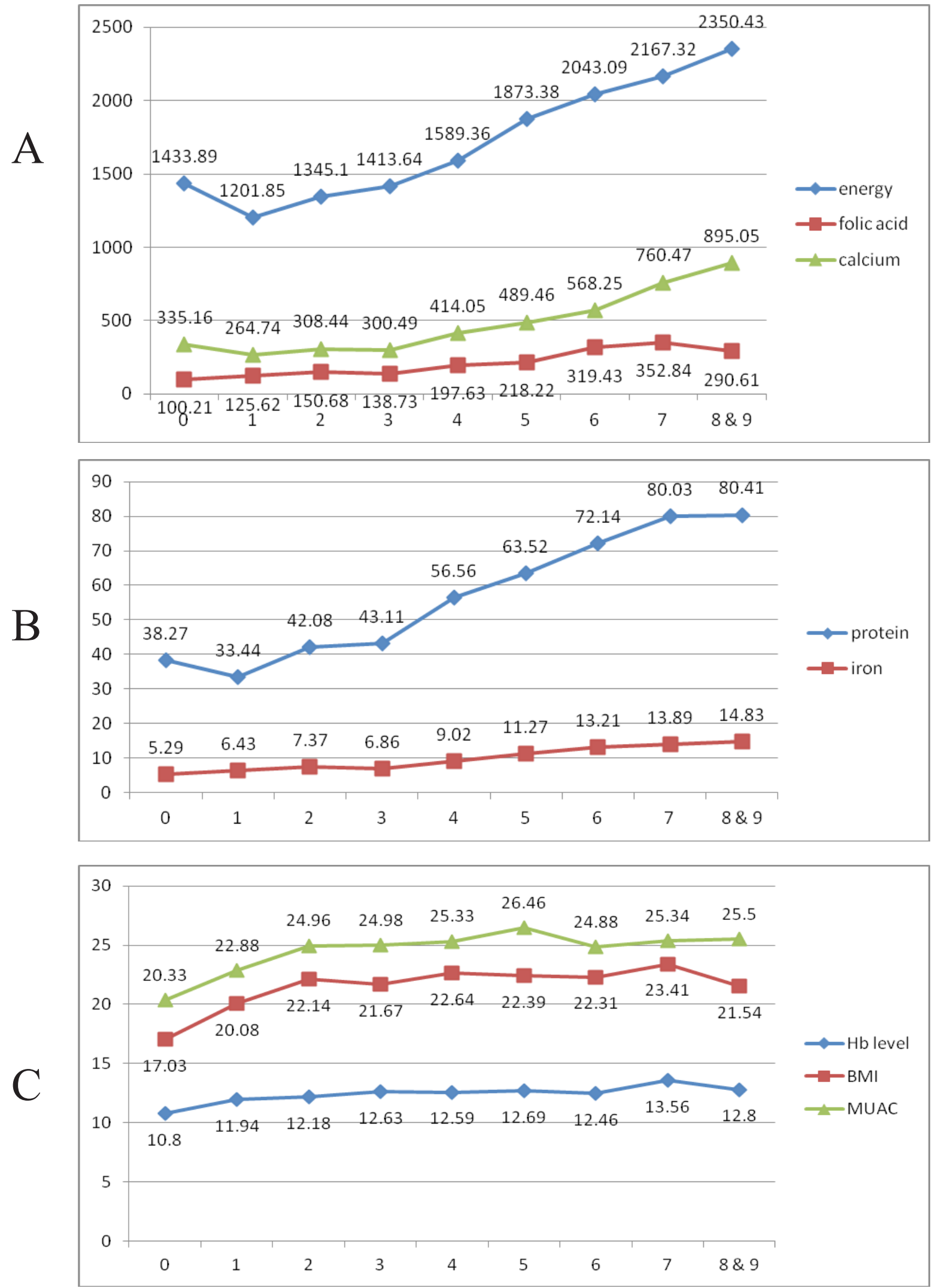

Fig 3. Mean of energy, folic acid, and calcium intake (A); protein and iron intake (B); Hb level, BMI, and MUAC (C); based on the score of preconception nutritional readiness. 
pregnant women often have to take iron-folic acid as well as calcium supplementation/fortification during pregnancy to meet their requirements. In the current study, only $23.4 \%$ of participants reported already consuming iron and/or folic acid supplements during their preconception period. Similar findings were found from study conducted in Spain, where the percentage of women of reproductive age consuming preconception folic acid supplements and multivitamins was only $48.9 \%$ and $14.1 \%$, respectively.(19) Regarding the level of knowledge about preconception nutrition, only $7.5 \%$ of participants demonstrated an adequate level of knowledge. Low understanding has been reported to be associated with low awareness of the importance of preparing for pregnancy beginning in the preconception period. $(13,23)$

In their review, Stephenson et al.,(13) conclude that many women of reproductive age in low, middle, and high-income countries are not nutritionally prepared for pregnancy. Similar to our study results, another systematic review also found that preconception women may not be meeting the minimum requirements of dietary guidelines and/or nutritional recommendations.(24) Several studies also shown a lack of awareness about preconception nutrition among women of reproductive age.(25-28) In a qualitative study, it was revealed that the reason many women do not consider preconception nutrition to be necessary is because there is no child yet.(25) One study in Southampton, UK found a significant reduction in smoking, alcohol consumption, and intake of caffeinated drinks when women became pregnant.(9) Although this study looked at different variables, it supports the results of the current study that women's awareness of the importance of preconception health is still low.

The preconception nutrition readiness of the women who participated in the current study was not found to be significantly different among sociodemographic factors. Women of a younger age, with a higher educational background, not working, or with lower income levels, were found to have a slightly lower score of preconception nutrition readiness. Furthermore, the current study found that if more indicators of preconception nutrition readiness were met, the average dietary intake of energy, protein, iron, folic acid, and calcium was higher too. This positive association showed that preconception nutrition readiness scores may be useful for assessing nutritional adequacy in women of reproductive age. The higher the score obtained, the more adequate the nutritional intake tends to be.

Meanwhile, the indicators that were met by the majority of participants included $\mathrm{Hb}$ levels, nutritional status, and MUAC. These three indicators are important predictors for pregnancy outcomes. Many previous studies found that pre-pregnancy nutritional status dan $\mathrm{Hb}$ levels can affect pregnancy and the outcomes. Regarding $\mathrm{Hb}$ levels, the current study found that more than $20 \%$ of the women of reproductive age in our sample were anemic. The prevalence of anemia in this population of reproductive age women is significantly lower than that found in Indonesian pregnant women.(10) One study in India also found a high prevalence of anemia, with about $40.0 \%$ of women having mild anemia, $13.0 \%$ having moderate anemia, and $1.4 \%$ having severe anemia.(29) Based on Global Health Observatory data repository by WHO conducted in 2016, the prevalence of anemia among women of reproductive age in South East Asia region was estimated to be $45.8 \%$.(30) Several studies have shown the adverse effect of preconception anemia on the pregnancy outcomes. $(22,31)$

Regarding to nutritional status, pre-pregnancy nutritional status is one of the factors that can affect pregnancy outcomes. Both underweight and overweight/obese have adverse effects on pregnancy outcomes. $(2,5,16,32-34)$ In the current study, the prevalence of underweight (BMI $<18.5$ $\mathrm{kg} / \mathrm{m}^{2}$ ) women was $19.2 \%$, while the prevalence of overweight (BMl>25.0 kg/m²) was $18.0 \%$. A previous study among premarital women of reproductive age found similar results; $22.9 \%$ of the women were underweight and $22.3 \%$ were overweight. (35) Moreover, a study in Thailand found that the prevalence of pre-pregnancy underweight (BMI $<18.5 \mathrm{~kg} / \mathrm{m} 2)$ and overweight (BMI $\geq 25 \mathrm{~kg} / \mathrm{m} 2)$ were $17.2 \%$ and $14.3 \%$, respectively.(33)

The risk of chronic energy deficiency, based on a MUAC cut-point of $<23.5 \mathrm{~cm}$, is also prevalent 
among this study population. More than $40 \%$ of participants were found to be at risk of chronic energy deficiency. MUAC is also an important predictor of pregnancy outcomes. Several studies have found that maternal MUAC is associated with low birth weight,(36-38) preterm births, and small for gestational age.(37)

It is well known that there is an association between preconception BMI, MUAC, and $\mathrm{Hb}$ levels with pregnancy outcomes. Aforementioned, in the current study, BMI, MUAC, and Hb levels were the three most fulfilled indicators. The results of the correlation analysis between the most fulfilled indicators and each indicator of readiness showed that BMI only had a strong and significant correlation with MUAC, while $\mathrm{Hb}$ levels had a significant but weak correlation with protein and folic acid intake. The indicators related to food intake were weakly correlated with BMI, MUAC, and Hb levels. This result may lead to the reconsideration that meeting the ten indicators of readiness may not be a requirement, and maybe food intake is not the main indicator. Food intake during preconception can be different from intake during pregnancy.(39)

The findings from the current study provide an overview of women's nutritional readiness prior to pregnancy. However, future research is needed to prove that preconception nutrition readiness can affect maternal health conditions during pregnancy, and ultimately, pregnancy outcomes.

\section{CONCLUSION AND RECOMMENDATION}

In summary, the number of women of reproductive age who were nutritionally ready for enter pregnancy was very low. The preconception nutrition readiness indicators that were not fulfilled included indicators related to micronutrient intake. On the contrary, the indicators that were fulfilled by the majority of participants, such as nutritional status, MUAC, and $\mathrm{Hb}$ levels, should continue to be prioritized to ensure a healthy pregnancy.

Although socio-demographic factors were not statistically significantly associated with preconception nutrition readiness, the findings of the current study illustrate that women of younger age, who are unemployment, and lower-income, demonstrate slightly lower preconception nutrition readiness scores. The current study suggests that a more serious preconception health care program be implemented to prepare women for healthy pregnancy. Education is needed to raise awareness about the importance of preconception nutrition preparation among women of reproductive age who are planning a pregnancy.

\section{Acknowledgement}

The authors thank all of the women who agreed to participate voluntarily in this study, as well as the research team who collected the data. Furthermore, the support of CAPTURE (Community - Alma Ata Partnership Through Updated Research and Education) of Alma Ata University, Yogyakarta, Indonesia, is gratefully acknowledged.

\section{Funding}

Indonesia Endowment Fund for Education, Ministry of Finance.

\section{Conflict of Interest}

The authors do not have any conflict of interest.

\section{REFERENCES}

1. Siega-Riz AM, Viswanathan M, Moos MK, Deierlein A, Mumford S, Knaack J, et al. A systematic review of outcomes of maternal weight gain according to the Institute of Medicine recommendations: birthweight, fetal growth, and postpartum weight retention. American Journal of Obstetrics and Gynecology. 2009.

2. Ramakrishnan U, Grant F, Goldenberg T, Zongrone A, Martorell R. Effect of women's nutrition before and during early pregnancy on maternal and infant outcomes: A systematic review. Paediatric and Perinatal Epidemiology. 2012.

3. Haider BA, Olofin I, Wang M. Anaemia, prenatal iron use, and risk of adverse pregnancy outcomes: systematic review and meta-analysis. BMJ. 2013;346:1-19. 
4. Barker M, Dombrowski SU, Colbourn T, Fall CHD, Kriznik NM, Lawrence WT, et al. Preconception health 3 Intervention strategies to improve nutrition and health behaviours before conception. 1853;1853-64.

5. Dean S V, Lassi ZS, Imam AM, Bhutta ZA. Preconception care : nutritional risks and interventions. Reprod Health [Internet]. 2014;11(Suppl 3):S3. Available from: http://www. reproductive-health-journal.com/content/11/S3/ S3

6. Hemsing N, Greaves L, Poole N. Sexual \& Reproductive Healthcare Preconception health care interventions: A scoping review. Sex Reprod Healthc [Internet]. 2017;14:2432. Available from: https://doi.org/10.1016/j. srhc.2017.08.004

7. Dean S, Rudan I, Althabe F, Girard AW, Howson C, Langer A, et al. Setting Research Priorities for Preconception Care in Low- and MiddleIncome Countries : Aiming to Reduce Maternal and Child Mortality and Morbidity. PLoS Med. 2013;10(9):e1001508.

8. World Health Organization. Preconception care: Maximizing the gains for maternal and child. 2013.

9. Crozier SR, Robinson SM, Borland SE, Godfrey $\mathrm{KM}$, Cooper C. Do women change their health behaviours in pregnancy? Findings from the Southampton Women's Survey. Paediatr Perinat Epidemiol. 2009;23(5):446-53.

10. Kemenkes R. Laporan Nasional RISKESDAS 2018 [Internet]. Badan Penelitian dan Pengembangan Kesehatan. 2019. Available from: http://labdata.litbang.kemkes.go.id/ images/download/laporan/RKD/2018/Laporan_ Nasional_RKD2018_FINAL.pdf

11. Daulay SM, Mulyani EY, Bahar H. Perbedaan Asupan Zat Besi, Kalsium, Vitamin C, dan Asam Folat dengan Kejadian Anemia Pada Wanita Usia Subur Usia 15-45 tahun di Pulau Sulawesi (Analisis Data Sekunder Riskesdas 2007) [Internet]. 2015. Available from: https:// digilib.esaunggul.ac.id/perbedaan-asupan-zatbesi-kalsium-vitamin-cdan-asam-folat-dengankejadian-anemiapada-wanita-usia-subur- wusdi-pulau-sulawesianalisis-data-sekunder-riskesdas-2007-5733.html

12. Hadi $\mathrm{H}$, Irwanti W. High Deficit in Nutrient Intakes Was Associated with Poor Nutritional Status of Pregnant Women: A Study from Eastern Indonesia. Curr Dev Nutr. 2020;4(Supplement_2):199-199.

13. Stephenson J, Heslehurst N, Hall J, Schoenaker DAJM, Hutchinson J, Cade JE, et al. Before the beginning: nutrition and lifestyle in the preconception period and its importance for future health. Lancet [Internet]. 2018;391(10132):183041. Available from: http://dx.doi.org/10.1016/ S0140-6736(18)30311-8

14. Grieger JA, Grzeskowiak LE, Clifton VL. Preconception Dietary Patterns in Human Pregnancies Are Associated with Preterm Delivery. J Nutr [Internet]. 2014;144(7):107580. Available from: http://jn.nutrition.org/cgi/ doi/10.3945/jn.114.190686

15. Schummers L, Hutcheon JA, Bodnar LM. Risk of Adverse Pregnancy Outcomes by Prepregnancy Body Mass Index: A Population-Based Study to Inform Prepregnancy Weight Loss Counseling. Obs Gynecol. 2015;125(1):133-43.

16. Shin D, Song WO. Prepregnancy body mass index is an independent risk factor for gestational hypertension, gestational diabetes, preterm labor, and small- and large-for-gestationalage infants. J Matern Neonatal Med [Internet]. 2015;28(14):1679-86. Available from: http:// www.tandfonline.com/doi/full/10.3109/147670 58.2014 .964675

17. Harelick L, Viola D, Tahara D. Preconception Health of Low Socioeconomic Status Women : Assessing Knowledge and Behaviors. Women's Heal Issues [Internet]. 2011;21(4):272-6. Available from: http://dx.doi.org/10.1016/j. whi.2011.03.006

18. Dunlop AL, Logue KM, Thorne C, Badal HJ. Change in Women's Knowledge of General and Personal Preconception Health Risks Following Targeted Brief Counseling in Publicly Funded Primary Care Settings. Am J Heal Promot. 2013;27(3 Supplement):S50-7. 
19. Cuervo M, Sayon-orea C, Santiago S, Martínez JA. Dietary and Health Profiles of Spanish Women in Preconception, Pregnancy and Lactation. Nutrient. 2014;6:4434-51.

20. World Health Organization. Meeting to develop a global consensus on preconception care to reduce maternal and childhood mortality and morbidity [Internet]. WHO Headquarters, Geneva Meeting report. Geneva. 2013. Available from: https://www.who.int/maternal_child_adolescent/ documents/concensus_preconception_care/en/

21. Kemenkes R. Peraturan Menteri Kesehatan RI Nomor 41 Tahun 2014 tentang Pedoman Gizi Seimbang [Internet]. 2014. Available from: http:// hukor.kemkes.go.id/uploads/produk_hukum/ PMK No. $41 \mathrm{ttg}$ Pedoman Gizi Seimbang.pdf

22. World Health Organization. Nutrition of women in the preconception period, during pregnancy and the breastfeeding period. 2012.

23. Goshu YA, Liyeh TM, Ayele AS, Zeleke LB, Kassie YT. Women's awareness and associated factors on preconception folic acid supplementation in Adet, Northwestern Ethiopia, 2016: Implication of reproductive health. J Nutr Metab. 2018;2018.

24. Caut C, Leach M, Steel A. Dietary guideline adherence during preconception and pregnancy : A systematic review. Matern Child Nutr. 2020;16:e12916.

25. Szwajcer EM, Hiddink GJ, Koelen MA, van Woerkum CMJ. Nutrition awareness and pregnancy: Implications for the life course perspective. Eur J Obstet Gynecol Reprod Biol. 2007;135(1):58-64.

26. Mitchell EW, Levis DM, Prue CE. Preconception Health: Awareness, Planning, and Communication Among a Sample of US Men and Women. Matern Child Health J. 2010;16:31-9.

27. Stephenson J, Patel D, Barrett G, Howden B, Copas A, Ojukwu O, et al. How Do Women Prepare for Pregnancy? Preconception Experiences of Women Attending Antenatal Services and Views of Health Professionals. PLoS One. 2014;9(7):e103085.

28. Inskip H, Crozier SR, Godfrey KM, Borland SE, Cooper C, Robinson SM. Women's compliance with nutrition and lifestyle recommendations before pregnancy: general population cohort study. BMJ. 2009;338:b481.

29. Singh RK. Lifestyle behavior affecting prevalence of anemia among women in EAG states, India. J Public Health (Bangkok). 2013;21:279-88.

30. World Health Organization. Global Health Observatory data repository. Prevalence of anaemia in women - Estimates by WHO region [Internet]. 2017. Available from: https://apps. who.int/gho/data/view.main.GSWCAH28REG

31. Ronnenberg AG, Wood RJ, Wang X, Xing $\mathrm{H}$, Chen $\mathrm{C}$, Chen $\mathrm{D}$, et al. Preconception Hemoglobin and Ferritin Concentrations Are Associated with Pregnancy Outcome in a Prospective Cohort of Chinese Women. J Nutr. 2004;134:2586-91.

32. Ronnenberg AG, Wang X, Xing H, Chen C, Chen D, Guang W, et al. Low Preconception Body Mass Index Is Associated with Birth Outcome in a Prospective Cohort of Chinese Women. J Nutr. 2003;133:3449-55.

33. Pongcharoen $T$, Gowachirapant $S$, Wecharak P, Sangket N, Winichagoon P. Pre-pregnancy body mass index and gestational weight gain in Thai pregnant women as risks for low birth weight and macrosomia. Asia Pac J Clin Nutr. 2016;25(4):810-7.

34. Aji AS, Yusrawati Y, Malik SG, Lipoeto NI. Pre-Pregnancy Maternal Nutritional Status and Physical Activity Levels During Pregnancy Associated with Birth Size Outcomes in Minangkabau Women, Indonesia. Curr Dev Nutr. 2020;4(Supplement_2):931-931.

35. Paratmanitya $\mathrm{Y}$, Hadi $\mathrm{H}$, Susetyowati. Citra tubuh, asupan makan, dan status gizi wanita usia subur pranikah. J Gizi Klin Indones. 2012;8(3):126-34.

36. Assefa N, Berhane Y, Worku A. Wealth status, mid upper arm circumference (MUAC) and Antenatal Care (ANC) are determinants for low birth weight in Kersa, Ethiopia. PLoS One. 2012;7(6):e39957.

37. Sebayang SK, Dibley MJ, Kelly PJ, Shankar A V., Shankar AH. Determinants of low birthweight, small-for-gestational-age and preterm birth in Lombok, Indonesia: Analyses of the birthweight 
cohort of the SUMMIT trial. Trop Med Int Heal. 2012;17(8):938-50.

38. Ververs M, Antierens A, Sackl A, Staderini N, Captier V. Which Anthropometric Indicators Identify a Pregnant Woman as Acutely Malnourished and Predict Adverse Birth
Outcomes in the Humanitarian Context ? PLoS Curr. 2013;5(June 7).

39. Hillier SE, Olander EK. Women's dietary changes before and during pregnancy: A systematic review. Midwifery. 2017;49:19-31. 